\title{
Migration, Jobs, and Real Exchange Rates in the Philippines
}

\author{
Alberto Chong \\ Georgia State University, Atlanta, United States \\ Universidad del Pacífico, Lima, Perú
}

\begin{abstract}
This study tests whether exchange rate appreciation due to migration is tempered by the hiring of part-time workers. Quarterly data from 1994 to 2015 for the Philippines are employed. We find that not only increase in remittances, but also increase in migration appreciates real exchange rate. The results also show that underemployment tends to depreciate the exchange rate, which implies that the hiring structure does have a role on the long run real effective exchange rate.
\end{abstract}

JEL Classification: F24, F31, O10

Keywords: Migration, Remittances, Exchange rate, the Philippines, Cointegration

\footnotetext{
* Corresponding Author: Alberto Chong; Professor, Andrew Young School of Policy Studies, Department of Economics, Georgia State University, 14 Marietta St., Room 516, Atlanta, GA 30303, USA, Tel: 404-413-0201, Fax: 404-413-0145, Email: achong6@gsu.edu 


\section{Introduction}

It is well known that remittances in developing countries are a substantial source of current account credits, exerting macroeconomic influence. This is particularly important in the Philippines where nominal dollar remittances surpassed 25 billion US dollars in 2016 and equivalent to nearly ten percent of the Gross Domestic Product (GDP) (World Bank 2016). Remittances from Overseas Filipino workers (OFW) have helped increase international reserves. By the end of 2015, Philippines' international reserves amounted to more than 80 billion US dollars, which is equivalent to almost one year of imports and nearly six times the country's short-term external liability by residual maturity (World Bank 2016).

Despite its statistical magnitude, the study on the real exchange rate and remittances is relatively scarce. To our knowledge there is no formal empirical study focusing on the impact of remittances on the exchange rate in the Philippines. The Philippines is the first country to promote a policy of encouraging overseas foreign workers, as a result, its inflows for remittances remain among the highest in the world. Today, it is arguably the most successful labor-sending and remittance-receiving country in the East Asia and Pacific region. Filipino workers are being employed in an extraordinarily diverse countries (McKenzie et al. 2012) ${ }^{1}$.

It is often overlooked that migration may affect household through its impact on the recipient households' labor supply and wage. When a large proportion of the working population migrates out, the domestic labor market experiences a supply shock creating an upward pressure on wages. This can potentially impact the real exchange rate and thus lead to changes in incentives and the sectoral distribution of labor. Despite significant increases in emigration from the Philippines, the rate of migration as a share of the overall labor force still remain relatively modest. Thus it is debatable whether large-scale migration increases wages in the Philippines given the modest share of migrants in the labor force. However, even without a change in the equilibrium wage, incentives for workers from non-migrating families are likely to be affected (World Bank 2016) ${ }^{2}$.

\footnotetext{
${ }^{1}$ In general, migration from the Philippines is largely temporary and legal, and occurs through licensed private recruitment agencies. Overseas temporary contract work is the primary channel through which Filipinos migrate, an OFW must have a job contract in hand (McKenzie et al. 2012)

${ }^{2}$ After depreciating in 1995 the exchange rate goes from around 403 pesos per US dollar to around 303 pesos per US dollar in 2005.
} 
Migration and remittances are inextricably intertwined. Migration is a key economic and social development issue in the Philippines and often motivated by the desire to improve the welfare of those who left behind mainly by sending them money (Niimi and Ozden 2008). Due to poor economic conditions, the Philippine government began the Overseas Employment Program in 1974 which was designed to assist Filipinos in finding overseas work. After the program's inception Filipino migration has increased dramatically. The growth rate of Filipino labor force employed abroad grew by slightly above 10 percent during the period of 1995 2005 and grew by over 58 percent during the period of 2006 2015 (Philippines Statistics Authority 2016).

This study looks into the association between migration, understood as subsequent remittances, and possible real exchange appreciation. The hypothesis is as follows: migration decreases the labor supply in the local market leading to an upward pressure on wages. The rising wages increase production costs and, holding all else constant, it lowers the competitiveness of the tradable sector. Such contraction causes the real exchange rate to appreciate. This mechanism is in addition to the standard trade mechanisms commonly found in the literatures which propose that large capital inflows stemmed from remittances increase wealth. Such increase, combined with exogenous trade prices, raises the price of non-tradable goods and services leading to an expansion of the non-tradable sector. The rise in the price of non-tradables relative to tradables then translates into real exchange rate appreciation. Furthermore, the expansion of the non-tradable sector increases demand for resources putting additional pressure on real exchange rate to appreciate (Lopez et al. 2008). The proposed mechanism is different from another well-known channel: remittances increase household wealth and decrease labor supply because wealthier households substitute more leisure for work. Reduced labor supply then increases wages so that production costs rise leading to the contraction of tradable sector contracts (Barajas et al. 2010).

\footnotetext{
Furthermore, the real exchange rate began to appreciate in 2006 and reaching around 387 US dollars in 2015 (Real Effective Exchange Rates with US dollars of 1997 as base year) (International Finance Statistics and International Monetary Fund 2017). Similarly, after spiking in 1998, the share of remittances of GDP increased from 7.3 percent in 1999 to over 10 percent in 2000 2005 and 2009, while the real exchange rate increased from a low of 286 in 2004 to 399 in 2009. This trend in the REER appears to be consistent with movements in the labor market, especially with respect to emigration of Overseas Filipino Workers (OFW) and employment in the domestic market as corroborated by recent studies by the World Bank (2012).
} 
Regardless of the mechanism, the key issue is that both resource reallocation and labor supply effects cause an appreciation of the real exchange rate, thereby reducing the international competitiveness of the tradable sector. This may translate into higher wages, production costs, contraction of the tradable sector and possibly lowered productivity.

The above is further compounded by the fact that in the Philippines, currently nearly forty percent of the employed labor force works on a contractual basis, either part-time or full-time. As of the end of 2015, the Philippines' underemployment ${ }^{3}$ rate was 22 percent (World Bank 2016). In addition, workers awaiting overseas job opportunities and belonging to nonremittance receiving families (often belonging to the bottom 5 percent of the income distribution) are willing to work on a contractual or part-time basis, which results in excess labor supply. Employers are hence willing to hire more temporary workers to reduce labor associated costs such as minimum wage requirement, health insurance and pension. Although this may help firms to maintain its cost competitiveness, it could lead firms to high turnover rates since temporary workers can leave their position when they find an overseas job. Under this situation firms do not have the incentive to invest in human capital, which results in no skill development for workers, creates redundancies and ultimately lowers productivity.

This paper tests whether exchange rate appreciation due to migration and remittances is tempered by the hiring of contractual, temporary, or part-time workers, keeping labor productivity at a low level. More specifically, we apply a Vector Error Correction Model (VECM) and test the link between underemployment and the real exchange rate controlling for remittances and migration. Time-series quarterly data from the National Statistical Coordination Board are employed over the period of the first quarter of 1994 to the third quarter of 2015. Results suggest that increases in remittances and migration appreciates real exchange rate. Underemployment tends to depreciate the exchange rate, which implies that the hiring structure does have a role on the long run real effective exchange rate.

The paper is organized as follows. Section $I$ provides a brief review of the literature. Section III provides some basic stylized facts and describes the data and the methodology. Section IV presents the findings on real exchange

${ }^{3}$ Underemployed individuals are those who are employed and desire to have additional hours of work in their present job or in an additional job, or to have a new job with longer working hours (International Monetary Fund, 2017) 
rates using the VECM approach and Section V concludes.

\section{Literature}

While several studies focus on the role of remittances on the exchange rate, there is no clear consensus on whether the real exchange rate appreciates as a result of inflow remittances. Amuedo-Dorantes and Pozo (2004) relies on panel techniques and finds that a doubling of workers' remittances lead on average to a overvaluation of real exchange rate about 22 percent in the sample of Latin American countries. Bourdet and Falck (2003) finds a qualitatively similar result for Cape Verde over the period of 1980 2000. Studies on other countries using different empirical methods also find similar results (Hyder and Mahboob 2005, Lopez et al. 2007, Acosta et al. 2009, Barajas et al. 2010).

However, Izquierdo and Montiel (2006) shows mixed results in the case of Central American countries over the period of 1960 2004. In some cases, such as Honduras, Jamaica, and Nicaragua, it finds no link between remittances and the real exchange rates, but in others, such as Dominican Republic, El Salvador, and Guatemala, it finds an appreciation of the longrun real exchange rate when remittances increase. Furthermore, Acosta et al. (2009) states that while remittances tend to put upward pressure on the real exchange rate, its impact is weaker in the countries with deeper and more sophisticated financial markets, enabling them to retain trade competitiveness. It appears that the financial sector mitigates local currency appreciation and helps the domestic economy remain internationally competitive.

There are evidences that remittances can increase physical and human capital at the household level (Cox et al. 2003, Woodruff and Zenteno 2007, Fajnzylber and Lopez 2008, Yang 2008) and affect poverty (Acosta et al. 2008). For the case of El Salvador, Cox et al. (2003) shows that remittances increase retention rates in school. Adams and Cuecuecha (2010) finds that Guatemalan households receiving remittances spend more on education than what they would have spent without remittances. Mansuri (2007) argues that migration leads to higher school attainment, especially for girls, in rural Pakistan. Yang (2008) finds that an appreciation of the exchange rate, which implies higher remittances, in Philippines increases the likelihood of 
attending school for children aged 10 to 17 years and decreases their working hours.

However, there is no consensus in these finding. As described in the report by the World Bank (2010), several empirical studies find a negative impact of migration or remittances on the labor supply of non-migrant family members. For instance, Acosta et al. (2008) exhibits mixed results regarding the relation between remittances and educational outcomes in Latin America. Furthermore, it has been shown that migration and remittances have a significant negative impact on school attendance and attainment in Mexico. (McKenzie 2006, McKenzie and Rapoport 2006) ${ }^{4}$. Kim (2007) finds, in Jamaica, a reduction in labor force participation of household members staying behind. Similarly, Acosta (2007) shows that receiving remittances leads to fewer working hours and a fall in labor force participation for women, but not for men in El Salvador.

For the Philippines, Rodriguez and Tiongson (2001) finds evidence that families with OFW are less likely to participate in the labor force, but Ducanes and Abella (2008) does not report a similar results. Yang (2008) shows that a positive income shock stemmed from exchange rate shock on the Philippine peso during the Asian financial crisis did not affect the total working hours of non-migrant household members. However, the time spent in self-employment activities increased. Migration may also reduce the total working hours per week of all household members by 26 (Nguyen and Purnamasari 2011). Tullao et al. (2004) finds that households with remittances exhibit lower labor force participation and employment rates compared to households without remittances. In general, a negative impact of remittances on the labor supply of remaining household members is not necessarily a concern unless work incentives are also distorted (World Bank 2010).

Remittances, however, are only half of the story. Migration is the other half. While obviously highly correlated, the transmission channel on the real exchange rates differs depending on whether it's driven by remittances or migration. Research on the impact of migration on exchange rates is practically non-existent. While the empirical evidence suggests that remittances tend to reduce labor supply, there is very scarce empirical evidence that migration tends to shift the labor supply to the point of putting

\footnotetext{
${ }^{4}$ According to McKenzie and Rapoport (2006) this finding is consistent with the lack of oversight due to an absent parent as well as the lower expected returns to education for Mexican children intending to migrate.
} 
pressure on wages, real exchange rate, and ultimately productivity.

\section{Data and Methodology}

The period for this research goes from the first quarter of 1994 to the third quarter of 2015. Data are publicly available and come from the Philippines Statistics Authority (PSA), the International Monetary Fund (IMF), and the World Bank (WB). Summary statistics for variables are shown in Table 1.

Methodologically, we employ unit root and cointegration techniques that are only valid asymptotically. In this context, our sample size is admittedly in borderline because the standard rule-of-thumb is that sample size for the application of this time-series techniques is expected to be around one hundred observations or higher. While all results presented below show great empirical consistency and several researchers have pointed out the sufficient sample sizes as the one employed in this paper (e.g. Giles 2014), it should be acknowledged that there might be a potential weakness originated from the sample size.

Table 1. Summary statistics for variables

\begin{tabular}{|l|c|c|c|c|c|}
\hline \multicolumn{1}{|c|}{ Variables } & Obs. & Mean & $\begin{array}{c}\text { Std. } \\
\text { Dev. }\end{array}$ & Min & Max \\
\hline Log(Real Effective Exchange Rate) & 92 & 4.914 & 0.136 & 4.244 & 4.944 \\
\hline Remittances (\% GDP) & 92 & 8.925 & 2.161 & 3.582 & 14.94 \\
\hline Government Expenditure (\% GDP) & 92 & 11.226 & 2.015 & 7.525 & 14.35 \\
\hline Openness (\% GDP) & 92 & 87.828 & 11.346 & 74.39 & 127.2 \\
\hline Net foreign assets (\%GDP) & 92 & 0.082 & 0.071 & -0.05 & 0.397 \\
\hline Log(GDP per capita) & 92 & 5.894 & 0.152 & 5.453 & 6.252 \\
\hline Overseas workers (\% labor force) & 92 & 3.852 & 0.773 & 2.472 & 5.093 \\
\hline Underemployed workers (\% employed) & 92 & 22.197 & 2.429 & 15.352 & 26.11 \\
\hline Log(Agriculture GDP by worker) & 92 & 5.853 & 0.1425 & 5.2495 & 5.932 \\
\hline Log(Industry GDP by worker) & 92 & 7.711 & 0.1127 & 7.2015 & 7.854 \\
\hline Log(Service GDP by worker) & 92 & 6.912 & 0.0814 & 6.6205 & 6.940 \\
\hline
\end{tabular}


The empirical specifications are as follows:

$$
\begin{aligned}
& \log R_{E E R_{t}}=\alpha_{o}+\alpha_{1} \operatorname{Rem}_{t}+\alpha_{2} \operatorname{Gex}_{t}+\alpha_{3} O P_{t}+\alpha_{4} F A_{t} \\
& +\alpha_{5} \log G D P p c_{t}+\varepsilon_{t} \\
& \log \text { REER }_{t}=\beta_{0}+\beta_{1} \text { Gex }_{t}+\beta_{2} O P_{t}+\beta_{3} F A_{t}+\beta_{4} \log G D P p c_{t} \\
& +\beta_{5} O F W_{t}+\varepsilon_{t} \\
& \operatorname{LogREER}_{t}=\gamma_{0}+\gamma_{1} \operatorname{Rem}_{t}+\gamma_{2} \text { Gex }_{t}+\gamma_{3} O P_{t}+\gamma_{4} F A_{t}+\gamma_{5} \log G D P p c_{t} \\
& +\gamma_{6} \text { Under }_{t}+\varepsilon_{t}
\end{aligned}
$$

where the subscript is the time period between the first quarter of 1994 and the third quarter of 2015. REER is the real effective exchange rate of the Philippines against a basket of the currencies of trading partners (IMF 2017). It represents a nominal effective exchange rate index adjusted for relative changes in consumer prices which is a proxy of cost indicators of the Philippines. Since it is defined as the relative price of domestic to foreign goods, an increase in REER implies a real exchange rate appreciation.

The explanatory variables include remittances (Rem), government expenditures (Gex), net foreign $\operatorname{assets}(F A)$ as a percentage of GDP and the logarithm of the GDP per capita $(\log G D P p c)$. The degree of openness of the economy $(O P)$ as a share of exports plus imports in GDP, Overseas Filipino workers $(O F W)^{5}$ as a percentage of the labor force, and the rate of underemployment (Under) as a share of total number of underemployed persons in a total number of employed persons ${ }^{6}$ are also employed. $\varepsilon_{t}$ is the error term.

Key variables of interest are $O F W$, Under and $\log G D P p c$. If our hypothesis is correct, an increase in $O F W$ will shift the labor supply curve to the left leading to increase in wages. As a results, the real exchange rate appreciate in the long run. Thus, the expected sign for $\beta_{4}$ is positive. We control for the underemployment rate which is a proxy for workers who work as a

\footnotetext{
${ }^{5}$ We define overseas Filipino workers as all Filipinos of 15 years of age or older outside the country (sea and land base) who have a work permit or are looking for a job.

${ }^{6}$ Underemployed individuals are those who are employed and desire to have additional hours of work in their present job or in an additional job, or to have a new job with longer working hours (International Monetary Fund, 2017)
} 
temporary or contract employee or in other similar categories. Although it does not capture the full range of worker types which this study would like to target, it may be taken as a variable that captures the lower bound of the full effect on long run real exchange rates because the correlation between underemployment and the others is quite high. Following Lopez et al. (2010) and Acosta et al. (2008), the logarithm of GDP per capita is included as a proxy for productivity. A higher GDP per capita is expected to increase income leading to increase in demand for non-tradable goods. As a result, the real effective exchange rate decrease.

Along the same lines, Anuendo and Pozo (2004) proxies for the BalassaSamuelson effect using GDP per capita anticipating that countries with higher per capita incomes will experience appreciating currencies. It states that researchers have attempted to directly account for relative appreciation by controlling for differences in productivity growth across sectors of the economy. Since data requirements for directly measuring productivity are taxing, GDP per capita is often used as a proxy for the anticipated bias in productivity that advances in relatively richer countries ${ }^{7}$.

In line with literature (e.g. Chowdhury and Rabbi 2011), government expenditures is employed as well. The motivation is that increases in government expenditure raise the demand for non-tradables when a dominant share of it is spent on non-tradable goods and services. In the short run, such excess demand bids up the price of non-tradables and results in real exchange rate appreciation. On the other hand, the real exchange rate depreciates if the larger share of government expenditure is spent on the tradable sector. Thus the sign of Gex can be either positive or negative (Chowdhury et al. 2011).

We also incorporate openness of the economy. Increased openness in the goods market through reductions in trade restrictions in form of tariff and quota, lowers the relative price of tradables to non-tradables and thus improves the trade competitiveness of a country. Reduction in tariff could make domestic goods more cost efficient and cheaper. Lower tariffs on capital imports also reduce the cost price of tradables and make the tradables sector more competitive (Chowdhury et al. 2011).

\footnotetext{
${ }^{7}$ In regards to productivity, technological advancement typically increases the productivity of the tradable sector which increases factor availability. By reducing the cost and price of tradables, increased productivity makes the tradable sector more competitive and tends to depreciate the real exchange rate. Supply effects of technological progress offset the demand effects according to the Rybczynski Theorem. However, if technology increases income and thus demand for non-tradables we can expect a reduction in the relative price of tradables to non-tradables. This can lead to a real appreciation. In this case, the demand effects of technological progress are greater than the supply effects producing $a$ Ricardo-Balassa effect (Chowdhury and Rabbi, 2011).
} 
Following Barajas et al. (2010), net foreign assets as share of GDP is incorporated as a proxy for capital inflows ${ }^{8}$. Inbound capital flows tend to appreciate the real exchange rate. Lastly, although there is no empirical evidence on the role of remittances on the real exchange rate in the Philippines, the variable Rem is included because the aim of this paper is to isolate the impact of underemployment and OFW on the exchange rate after controlling for remittances.

Strictly speaking, the relationship between remittances and the real exchange rate is ambiguous as the impact of increased remittances on the real exchange rate varies by the consumption, saving, and investment choices of the recipient families (Chowdhury et al. 2011). Inflow of remittances may increase the recipient families' consumption on non-tradables and/or affect recipient families' labor participation leading to increase of the relative price of non-tradables to tradables. As a results, real exchange rate appreciates. On the other hand, if recipient families increase saving and investment, remittances may lower the resource gap and raise investment in education, health and small businesses. It, in turn, would lower the relative price of nontradables to tradables and improve the international competitiveness of the country (Chowdhury et al. 2011).

\section{Results}

Table 2 presents basic results. The first three columns show the results that correspond to each of the Equation (1) to (3), and the latter three repeat the same but exclude the Net Foreign Assets variable.

${ }^{8}$ Unfortunately, we were not able to find a measure of quarterly foreign aid flows. 
Table 2. Workers, productivity, and the real exchange rate

\begin{tabular}{|c|c|c|c|c|c|c|}
\hline \multirow{2}{*}{ Variables } & \multicolumn{6}{|c|}{ Dependent Variable : Log(Real Effective Exchange Rate) } \\
\hline & [1] & [2] & [3] & [4] & [5] & [6] \\
\hline $\begin{array}{l}\text { Remittances } \\
(\% G D P)\end{array}$ & $\begin{array}{c}0.041 \\
{[0.003]^{* * *}}\end{array}$ & & $\begin{array}{c}0.039 \\
{[0.003]^{* * *}}\end{array}$ & $\begin{array}{c}0.185 \\
{[0.004]^{* * *}}\end{array}$ & & $\begin{array}{c}0.100 \\
{[0.004]^{* * *}}\end{array}$ \\
\hline $\begin{array}{l}\text { Government } \\
\text { Expenditure } \\
(\% G D P)\end{array}$ & $\begin{array}{c}-0.094 \\
{[0.002]^{* * *}}\end{array}$ & $\begin{array}{c}-0.130 \\
{[0.001]^{* * *}}\end{array}$ & $\begin{array}{c}-0.100 \\
{[0.002]^{* * *}}\end{array}$ & {$\left[\begin{array}{c}-0.010 \\
{[0.002]^{* * *}}\end{array}\right.$} & $\begin{array}{c}-0.018 \\
{[0.002]^{* * *}}\end{array}$ & $\begin{array}{c}-0.001 \\
{[0.001]^{* *}}\end{array}$ \\
\hline $\begin{array}{l}\text { Openness } \\
(\% G D P)\end{array}$ & {$\left[\begin{array}{c}0.000 \\
{[0.000]^{* * *}}\end{array}\right.$} & $\begin{array}{l}0.000001 \\
{[0.000]}\end{array}$ & $\begin{array}{c}0.00005 \\
{[0.000]^{* * *}}\end{array}$ & $\begin{array}{c}0.0004 \\
{[0.000]^{* * *}}\end{array}$ & $\begin{array}{c}0.002 \\
{[0.000]^{* * *}}\end{array}$ & $\begin{array}{c}0.00009 \\
{[0.000]^{*}}\end{array}$ \\
\hline $\begin{array}{l}\text { Net Foreign } \\
\text { Assets } \\
(\% \text { GDP })\end{array}$ & $\begin{array}{c}0.003 \\
{[0.000]^{* * *}}\end{array}$ & $\begin{array}{c}0.007 \\
{[0.001]^{* * *}}\end{array}$ & $\begin{array}{c}0.004 \\
{[0.000]^{* * *}}\end{array}$ & & & \\
\hline $\begin{array}{l}\log (G D P \text { per } \\
\text { capita) }\end{array}$ & {$\left[\begin{array}{c}-1.384 \\
{[0.005]^{* * *}}\end{array}\right.$} & $\begin{array}{c}-1.330 \\
{[0.007]^{* * *}}\end{array}$ & $\begin{array}{c}-1.335 \\
{[0.005]^{* * *}}\end{array}$ & $\begin{array}{c}-0.983 \\
{[0.050]^{* * *}}\end{array}$ & $\begin{array}{c}-1.453 \\
{[0.113]^{* * *}}\end{array}$ & $\begin{array}{c}-1.625 \\
{[0.011]^{* * *}}\end{array}$ \\
\hline $\begin{array}{l}\text { Overseas Foreign } \\
\text { workers } \\
\text { (\% labor force) }\end{array}$ & & $\begin{array}{c}-0.001 \\
{[0.001]}\end{array}$ & & & $\begin{array}{c}0.029 \\
{[0.010]^{* *}}\end{array}$ & \\
\hline $\begin{array}{l}\text { Underemployed } \\
\text { Workers } \\
\text { (\% Employed) }\end{array}$ & & & $\begin{array}{l}-0.00007 \\
{[0.000]^{* * *}}\end{array}$ & & & $\begin{array}{c}-0.021 \\
{[0.004]^{* * *}}\end{array}$ \\
\hline Observation & 92 & 92 & 92 & 92 & 92 & 92 \\
\hline $\begin{array}{l}\text { Akaike } \\
\text { Information } \\
\text { Criterion } \\
\end{array}$ & -68.13 & -41.25 & -61.45 & -43.43 & -20.12 & -53.18 \\
\hline $\begin{array}{l}\text { Hannan-Quinn } \\
\text { Information } \\
\text { Criterion }\end{array}$ & -67.22 & -41.84 & -61.34 & -42.12 & -20.46 & -52.16 \\
\hline $\begin{array}{l}\text { Schwarz } \\
\text { Bayesian } \\
\text { information } \\
\text { criterion }\end{array}$ & -64.19 & -41.50 & -59.33 & -40.52 & -20.26 & -51.39 \\
\hline
\end{tabular}

(Note) Data are quarterly, from first quarter 1994 to third quarter 2015. All estimations employ VECM Johansen normalization restriction imposed (Rank=1). Standard errors in brackets. * significant at $10 \% ; * *$ significant at $5 \% ; * * *$ significant at $1 \%$. Estimations were run using smoothed variables obtained through the Rodrik-Prescott seasonality filter. 
The most expected finding is that remittances appear to appreciate the long-run real exchange rate in the Philippines. The corresponding coefficient is positive and statistically significant at one percent as shown in the first column?. Proxy for productivity, $\log G D P p c$, yields a negative coefficient which is significant at the one percent significance level. It shows that gains in productivity are linked with depreciation in the real exchange rate.

A particularly noteworthy result is shown in the fifth column in Table 2. We find that the coefficient of $O F W$ is positive and statistically significant at five percent. It seems that migration is associated with an appreciation in the real exchange rate. This finding appears to be consistent with the hypothesis that migration provokes movements in the labor supply, pushes wages and costs up and, eventually, tends to appreciate the real exchange rate. However, this result does not appear to be robust. Changes in the specification render the $O F W$ coefficient statistically insignificant. Furthermore, the sign of the corresponding coefficient changes. This is shown in the second column of Table 2, where we control for capital inflows measured as net foreign assets.

The coefficient of underemployment rate is shown in column [3]. Workers in a precarious situation, those who are underemployed, are associated with a depreciation of exchange rate. This is consistent with the idea that employers hire more part-time, temporary or contractual workers to reduce labor associated costs to maintain their competitiveness. Finally, government expenditures yield a positive and statistically significant coefficient, and the net foreign assets are associated with an appreciation of the real exchange rate, just as Barajas et al. (2010).

Overall, results show that the labor structure does have a role on the movements of the long run real effective exchange rate in the Philippines. On the one hand, workers who are hired under precarious conditions are associated with a depreciation of the real exchange rate. It helps keep firms' competitive in the tradable sector and balancing the fact that migration of labor force tend to push the real exchange rate up. The issue, however, is whether this strategy by firms is reflected in terms of productivity of firms.

With respect to labor market rigidities and potential impacts of exchange rates on different sectors in the economy, Rajan and Subramanian (2005)

${ }^{9}$ In the Philippines households receiving remittances are typically not from the poorest part of the distribution. They tend to spend less at the margin on one key consumption good, namely food, and more at the margin on one investment good, typically housing (World Bank, 2011). 
analyses whether remittances have a different effects depending on the labor intensity of the various industries. Relying on a cross national dataset of 3-digit industry value added growth data, it finds that unlike other types of capital flows, particularly aid flows, remittances do not seem to have a negative impact on external competitiveness. It also argues that this could be the result of main uses of remittances: remittances are mostly spent on unskilled-labor intensive goods and services provided by micro-enterprises and thus having limited effects on the prices of skilled-labor intensive goods and other relatively scarce resources.

The results regarding the co-movement between different sectors in the Filipino economy and their impact on the long-run real exchange rate are reported in Table 3. We find that the elasticities between the real exchange rate and the three sectors (agriculture, industry, and services) do vary. The difference is statistically significant at one percent when applying corresponding $T$-tests. While the differences in elasticities may be indicative of the extent to which one sector is more tradable than other, the extent to which the differences are significant may point institutional rigidities among sectors $^{10}$. 
Table 3. Real exchange rate and sectors

\begin{tabular}{|c|c|c|c|}
\hline \multirow{2}{*}{ Variables } & \multicolumn{3}{|c|}{ Log(Real Effective Exchange Rate) } \\
\hline & [1] & [2] & [3] \\
\hline Log (Remittances as \% GDP) & $\begin{array}{c}0.324 \\
{[0.013]^{* * *}}\end{array}$ & $\begin{array}{c}0.211 \\
{[0.042]^{* * *}}\end{array}$ & $\begin{array}{c}0.125 \\
{[0.003]^{* * *}}\end{array}$ \\
\hline $\begin{array}{l}\text { Government Expenditure } \\
(\% G D P)\end{array}$ & $\begin{array}{c}0.001 \\
{[0.794]}\end{array}$ & $\begin{array}{c}-0.050 \\
{[0.012]^{* * *}}\end{array}$ & $\begin{array}{c}-0.005 \\
{[0.001]^{* * *}}\end{array}$ \\
\hline Openness (\% GDP) & $\begin{array}{c}0.001 \\
{[0.000]^{* * *}}\end{array}$ & $\begin{array}{c}0.003 \\
{[0.001]^{* *}}\end{array}$ & $\begin{array}{c}0.0001 \\
{[0.000]^{* *}}\end{array}$ \\
\hline $\begin{array}{l}\text { Log } \\
\text { (Agriculture GDP by workers) }\end{array}$ & $\begin{array}{c}-1.974 \\
{[0.170]^{* *}}\end{array}$ & & \\
\hline $\begin{array}{l}\text { Log } \\
\text { (Industry GDP by workers) } \\
\end{array}$ & & $\begin{array}{c}-1.101 \\
{[0.312]^{* * *}}\end{array}$ & \\
\hline Log(Service GDP by workers) & & & $\begin{array}{c}-1.793 \\
{[0.032]^{* * *}}\end{array}$ \\
\hline Observations & 92 & 92 & 92 \\
\hline Akaike Information Criterion & -42.13 & -45.28 & -43.11 \\
\hline $\begin{array}{l}\text { Hannan-Quinn Information } \\
\text { Criterion }\end{array}$ & -41.95 & -45.22 & -42.52 \\
\hline $\begin{array}{l}\text { Schwarz Bayesian information } \\
\text { criterion }\end{array}$ & -41.45 & -41.39 & -41.13 \\
\hline
\end{tabular}

(Note) Data are quarterly, from third quarter 1996 to fourth quarter 2010. All estimations employ a VECM Johansen normalization restriction imposed $($ Rank $=1)$. Standard errors in brackets. * significant at $10 \%$; ** significant at 5\%; *** significant at 1\%. AIC stands for Akaike Information Criterion; HQIC stands for Hannan-Quinn Information Criterion, and SBIC stands for Sawa Bayesian Information Criterion. Estimations were run using smoothed variables obtained through the Rodrik-Prescott seasonality filter.

To test the presence of unit roots for all variables, a modified Augmented Dickey-Fuller T-tests for unit root is applied. The series are transformed by a Generalized Least Squares (GLS) regression. We use three different methods to calculate the optimum number of lags and the results are shown in Table A1 in the Appendix. The results suggest one cannot reject, at 1 percent level 
of significance, the null hypotheses that the series are non-stationary in at least two of the tests. However, taking first differences of all the variables makes them stationary. Figure 1 shows that first differences of all series do not grow over time and have a fixed, stationary mean.

Figure 1. First differences
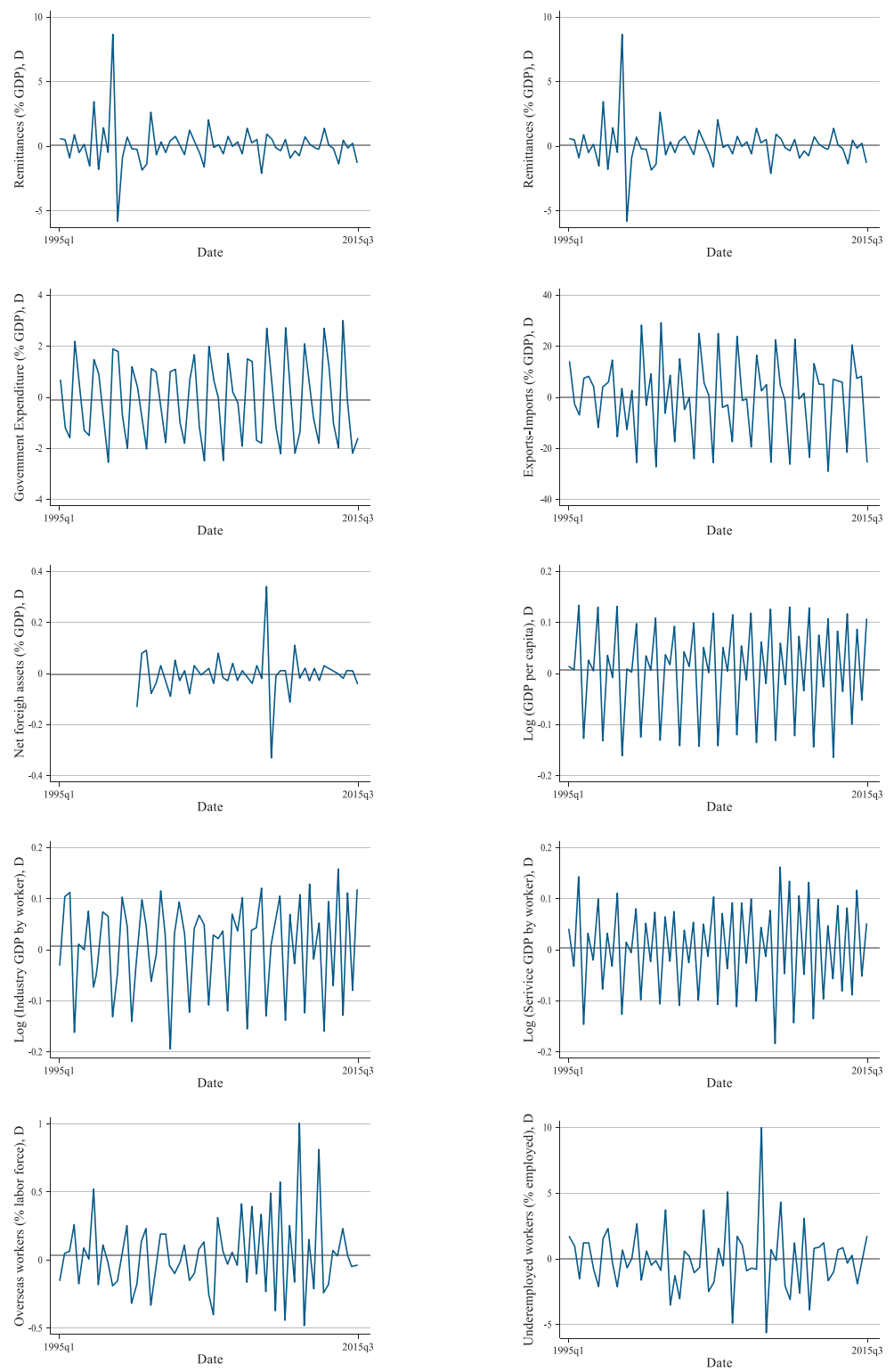
Since all variables appear to be I(1) processes, cointegration is tested by two methods. First, as suggested by Engle and Granger (1987), we run ordinary least squares regressions of the specifications presented above to check whether the residuals are stationary. The results are reported in Table A2 in the Appendix. In all the cases, the Augmented Dickey-Fuller test estimated through GLS rejects the null hypothesis of non-stationarity. Thus, there is cointegration. Johansen's test is applied as well whose testing procedure starts with the test for zero cointegrating equations, a maximum rank of zero, and repeat the tests with increasing ranks each time until the null hypothesis is not rejected. As shown in Table A3 in Appendix, the null hypothesis of no cointegration is rejected and the null hypothesis of at most one cointegrating equation is not rejected. Thus, using the Johansen identification scheme, we run specifications using a one equation VECM. ${ }^{11}$

\section{Conclusion}

This paper looks into the association between migration, real exchange appreciation, precarious jobs, and low labor productivity. The effects of underemployment on both the real exchange rate and productivity is highlighted for the specific case of the Philippines, a country where this kind of issues are of particular importance.

Using cointegration analysis, we find that whereas remittances appear to appreciate the real exchange rate, this upward pressure tends to be qualitatively tempered by the practice of firms of hiring temporary, parttime, or contractual workers in large percentages. Similarly, we also find an upward pressure on the real exchange rate from OFW, which is unsurprising and appears to confirm one of the premises this research starts with: OFW shifts the labor supply curve in the up and to the left that increases wages and helps appreciate the real exchange rate as a result. On the other hand, we also find firms appear to tap the unskilled in the form of part-time or pseudopermanent arrangements in order to keep its costs down, which dragged down the productivity. The pressure on the real exchange rate may be reduced by

\footnotetext{
${ }^{11}$ The movement of the real exchange rate from its sustainable long run position due to changes in real variables has significant consequences for policy evaluation as it can imply either gain or loss of external competitiveness. The above model incorporates the real and nominal factors affecting the observed REER both in the short and long run. The "fundamentals" or the real variables affect the equilibrium REER in the long run whereas the nominal variables impact on the REER only in the short run.
} 
increasing productivity in firms, particularly, in the non-tradable sector ${ }^{12}$.

In terms of future research with direct policy implications, a topic that warrants study is the role of brain drain and structural reform. On the one hand, migration may adversely affect growth through the disappearance of human capital, that is, brain drain. On the other hand, as seen in the existing literature, easy availability of remittances appears to reduce the incentives for reform. The lack of enough skilled labor may translate an economy below its potential in terms of growth and productivity, with relatively little pressure for structural reform. As the World Bank has indicated in previous reports (World Bank 2012), this combination may lead to a successful migrant country earning large external resources, but it allocates resources in a less productive way to generate growth and reduce poverty.

Received 4 July 2018, Revised 20 August 2018, Accepted 27 August 2018

\section{References}

Acosta, Pablo. "Labor supply, school attendance, and remittances from international migration: The case of El Salvador." World Bank Policy Research Working Paper 3903 (2006).

Acosta, Pablo Nicole Rae Baerg, and Federico S. Mandelman. "Financial Development, Remittances, and Real Exchange Rate Appreciation." Federal Reserve Bank of Atlanta Economic Review 94(1) (2009): 1-12.

Adams, R. "Remittances, Household Expenditure and Investment in Guatemala." Policy Research Working Paper Series 3532, The World Bank

\footnotetext{
${ }^{12}$ According to our findings using firm-level data, productivity may be increased by focusing on formal training, skills, and overall education of the labor force, with particular emphasis in the currently so-called temporal, part-time, or contractual workers. Furthermore, from an institutional perspective, improved enforcement of labor regulation may yield immediate returns in terms of productivity gains, all else remaining equal. From a practical perspective, this may be achieved by focusing on firms according to size, first the larger ones, who are the ones that yield the highest relative returns in terms of productivity gains and are also the ones that are relatively easy to target. Somewhat similar strategies have been applied in other countries, mostly in Latin America.
} 
Adams, R. and A. Cuecuecha. "Remittances, Household Expenditure and Investment in Guatemala." World Development 38(11) (2010):1626-1641.

Alberola, E., S. G. Cervero, H. López, and A. Ubide. "Global equilibrium exchange rates: euro, dollar, 'ins,' 'outs' and other major currencies in a panel cointegration framework." IMF Working Paper No.175 (1999).

Amuedo-Dorantes, Catalina, and Susan Pozo. "Workers' Remittances and the Real Exchange Rate: A Paradox of Gifts." World Development 32(8) (2004) :1407-17.

Barajas, Adolfo, Ralph Chami, Dalia S. Hakura, and Peter Montiel. "Workers' Remittances and the Equilibrium Real Exchange Rate: Theory and Evidence." IMF Working Paper 10/287 (2010).

Bourdet, Y., and H. Falck. "Emigrants' Remittances and Dutch Disease in Cape Verde.” International Economic Journal Vol. 20 (3) (2006) : 267-284.

Cabegin, E. and M. Alba. "More or Less Consumption? The Effect of Remittances on Filipino Household Spending Behavior." Manuscript. University of the Philippines (2011).

Chowdhury, M. and Fazle R. "Workers' Remittances and Real Exchange Rate in Bangladesh: A Cointegration Analysis." Manuscript, University of Western Sidney (2011).

Cox Edwards, Alejandra, and Manuelita Ureta. "International Migration, Remittances, and Schooling: Evidence from El Salvador." Journal of Development Economics 72, 2 (2003):429-61.

Darvas, Z. "Real Effective Exchange Rates for 178 Countries: A New Database.” Briegel Working Paper 2012/06 (2012). 
Ducanes, Geoffrey and Manolo Abella . "Overseas Filipino Workers and their Impact on Household Employment Decisions." ILO Asian Regional Programme on Governance of Labour Migration Working Paper No.8 (2008).

Engle, Robert F.; Granger, Clive W. J. (1987). "Co-integration and error correction: Representation, estimation and testing." Econometrica 55 (2): 251276.

Fajnzylber, Pablo, and J. Humberto Lopez, eds. "Remittances and development: Lessons from Latin America.” World Bank (2008).

Fuentes, J., and J. C. Herrera. "Emigrant Remittances and the Real Exchange Rate in Guatemala: An Adjustment-Costs Story." Manuscript, Bank of Guatemala (2007).

Giles, David (2014) http://davegiles.blogspot.com/2014/05/unit-root-testingsample-size-vs-sample.html.

Hanson, Gordon H. "Emigration, Remittances and Labor Force Participation in Mexico." Integration and Trade Journal 27 (July-December) (2007) : 73-103.

Hyder, Zulfiqar, and Adil Mahboob . "Equilibrium Real Effective Exchange Rate and Real Exchange Rate Misalignment in Pakistan." Manuscript, State Bank of Pakistan (2005).

International Monetary Fund International Finance Statistics (2017) http:// data.imf.org/?sk =4C514D48-B6BA-49ED-8AB9-52B0C1A0179B.

Izquierdo, Alejandro, and Peter J. Montiel. "Remittances and Equilibrium Real Exchange Rates in Six Central American Countries." Manuscript, Williams College (2006).

Johansen, S. "Estimation and Hypothesis Testing of Cointegrating Vectors in Gaussian Vector Autoregressive Models.” Econometrica 59, 1551- 80 (1991). 
Johansen, S., and K. Juselius, "Maximum Likelihood Estimation and Inference on Cointegration With Applications to the Demand for Money." Oxford Bulletin of Economic and Statistics 52(2) (1990): 169-210.

Kim, N. "The Impact of Remittances on Labor Supply: The Case of Jamaica." World Bank Policy Research Working Paper 4120 World Bank (2007).

López, Humberto, Luis Molina, and Maurízio Bussolo. "Remittances, the Real Exchange Rate, and the Dutch Diseases Phenomenon." In: Remittances and Development, Fajnzylber, Pablo and Humberto Lopez, eds., World Bank (2008).

McKenzie, David. "Beyond Remittances: The Effects of Migration Mexican Households." In C. Ozden and M. Schiff (eds) International Migration, Remittances and the Brain Drain. World Bank (2006): 123-147.

McKenzie, David. and Hilel Rapoport. "Can Migration Reduce Educational Attainment? Evidence from Mexico.” World Bank Policy Research Working Paper 3952 (2006).

McKenzie, David, Caroline Theoharides, and David Yang. "Distortions in the International Migrant Labor Market: Evidence from Filipino Migration and Wage Responses to Destination Country Economic Shocks." Manuscript, World Bank (2012).

Mansuri, Ghazala. "Does Work Migration Spur Investment in Origin Communities? Entrepreneurship, Schooling, and Child Health in Rural Pakistan." In C. Ozden and M. Schiff (eds), International Migration, Remittances and the Brain Drain. World Bank (2007).

Nguyen, T. and R. Purnamasari, "Impacts of International Migration and Remittances on Child Outcomes and Labor Supply in Indonesia: How Does Gender Matter?” Manuscript, World Bank (2010). 
Niimi, Yoko, and Caglar Ozden. "Migration and Remittances in Latin America: Patterns and Determinants." In: Remittances and Development, Fajnzylber, Pablo and Humberto Lopez, eds., World Bank (2008).

Philippines Statistics Authority (2016) https://www.psa.gov.ph.

Rajan Raghuram, and Arvind Subramanian."What Undermines Aid's Impact on Growth?” NBER Working Paper No. 11657 (2005).

Rodriguez, E. and E. Tiongson. "Temporary Migration Overseas and Household Labor Supply: Evidence from the Philippines." International Migration Review 35(3) (2001): 709-725.

Woodruff, C. and Zenteno, R. "Migration Networks and Micro-Enterprises in Mexico." Journal of Development Economics 82 (2) (2007): 509-528.

World Bank, Philippines: Fostering More Inclusive Growth, Human Development Sector Unit East Asia and Pacific Region Poverty Reduction and Economic Management Unit East Asia and Pacific Region, Washington, DC. (2010).

World Bank, International Migration and Development in the East Asia and Pacific Region Office of the Chief Economist, East Asia and Pacific Region, World Bank (2011).

World Bank, Philippines Quarterly Update, From Stability to Prosperity for All, March, Manila, Philippines (2016).

Yang, Dean. "International Migration, Remittances, and Household Investment: Evidence from Philippine Migrants' Exchange Rate Shocks." Economic Journal 118, 528 (2008):591-630.

Yu Sheng and Xinpeng Xu. "Real Exchange Rate, Productivity and Labour Market Efficiency: A Generalized Balassa-Sa muelson Model.” Manuscript, Australian National University (2007). 


\section{Appendix 1: Unit Roots Tests}

Table A1. Augmented Dickey Fuller: GLS unit root tests

\begin{tabular}{|l|c|c|c|}
\hline \multirow{2}{*}{ Variables } & \multicolumn{3}{|c|}{ Dickey Fuller GLS Test Statistics } \\
\cline { 2 - 4 } & Ng-Perron 1/ & Min SC 2/ & Min MAIC 3/ \\
\hline $\begin{array}{l}\text { Log } \\
\text { (Real Effective Exchange Rate) }\end{array}$ & -1.126 & -1.074 & -0.544 \\
\hline Remittances (\% GDP) & -2.068 & $-2.942^{*}$ & -1.321 \\
\hline $\begin{array}{l}\text { Government Expenditure } \\
\text { (\% GDP) }\end{array}$ & -0.336 & -1.938 & -0.184 \\
\hline Exports and Imports (\% GDP) & -0.767 & -1.316 & -0.945 \\
\hline Net Foreign Asset (\% GDP) & -1.983 & -1.363 & -0.636 \\
\hline Log(GDP per capita) & -2.196 & -2.369 & -1.744 \\
\hline Overseas workers (\% labor force) & -1.137 & -1.164 & -1.044 \\
\hline $\begin{array}{l}\text { Underemployed workers } \\
\text { (\% employed) }\end{array}$ & -2.269 & $-2.975 *$ & -1.962 \\
\hline Log(Agriculture GDP by worker) & -1.363 & -1.533 & -1.395 \\
\hline Log(Industry GDP by worker) & -1.569 & -2.052 & -1.371 \\
\hline Log(Service GDP by worker) & -1.391 & -1.644 & -1.086 \\
\hline
\end{tabular}

(Note) 1/,2/ and 3/ are three different procedures that estimate the optimal lag to be considered in order to apply the ADF test through GLS estimations. The null hypothesis assumes that all series are nonstationary;

* significant at $10 \%$ 

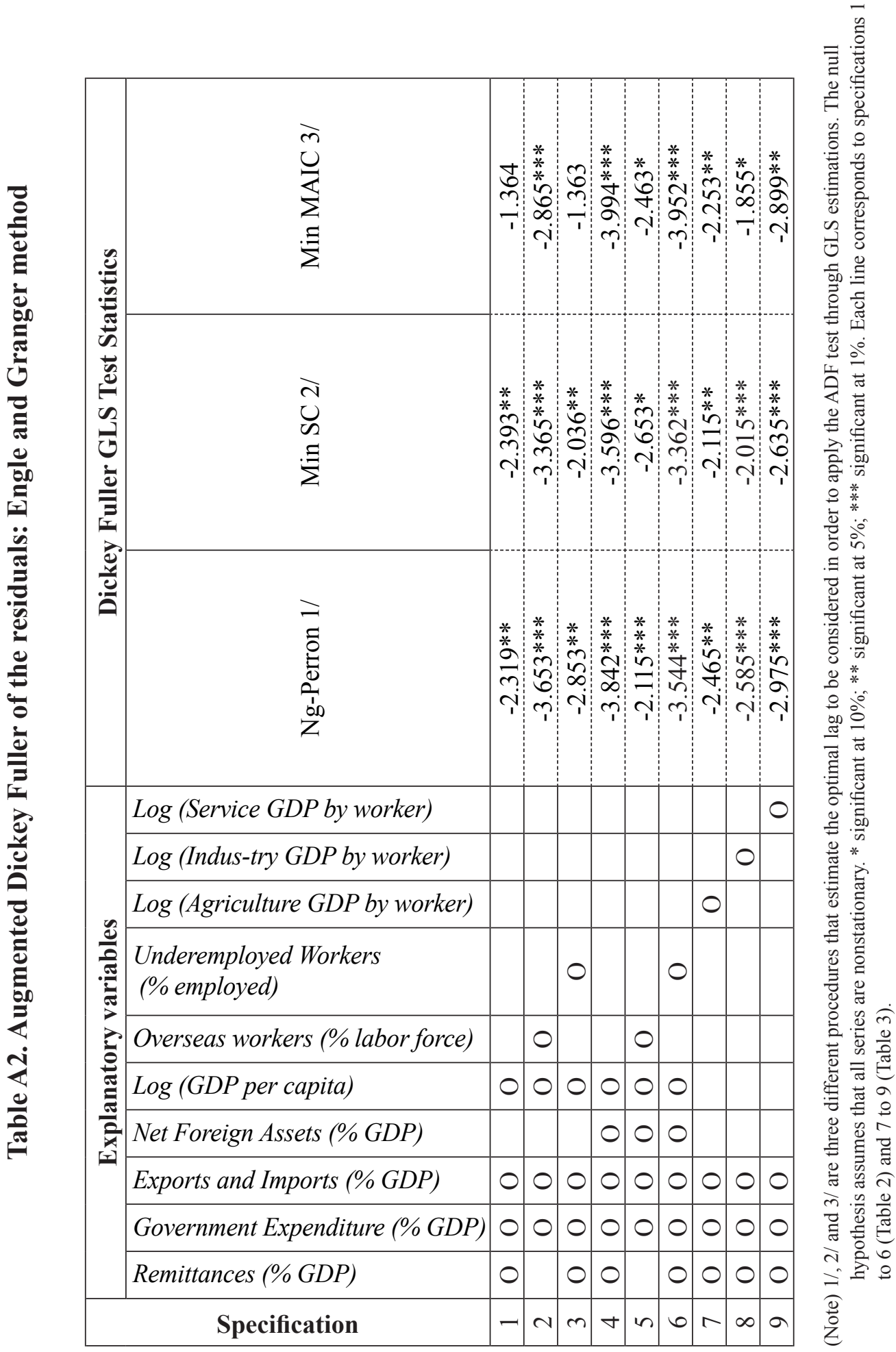
Table A3. Johansen rank test

\begin{tabular}{|l|c|c|c|c|}
\hline & Rank & Log-likelihood & Eigen-value & Trace Stastic \\
\hline \multirow{2}{*}{ Specification 1 } & 0 & 13.22 & - & 86.44 \\
\cline { 2 - 5 } & 1 & 38.58 & 0.60 & $38.19^{*}$ \\
\hline \multirow{2}{*}{ Specification 2 } & 0 & 120.64 & - & 91.14 \\
\cline { 2 - 5 } & 1 & 154.63 & 0.67 & $37.24^{*}$ \\
\hline \multirow{2}{*}{ Specification 3 } & 0 & -92.11 & & 98.64 \\
\cline { 2 - 5 } & 1 & -66.68 & 0.63 & $59.57^{*}$ \\
\hline \multirow{3}{*}{ Specification 4 } & 0 & 80.80 & & 117.14 \\
\cline { 2 - 5 } & 1 & 111.84 & 0.63 & $62.54^{*}$ \\
\hline \multirow{2}{*}{ Specification 5 } & 0 & 68.11 & & 147.25 \\
\cline { 2 - 5 } & 1 & 113.66 & 0.84 & $64.87^{*}$ \\
\hline \multirow{2}{*}{ Specification 7 } & 0 & -194.35 & & 99.05 \\
\cline { 2 - 5 } & 1 & -151.23 & 0.44 & $69.56^{*}$ \\
\hline \multirow{2}{*}{ Specification 8 } & 0 & -99.56 & & 102.15 \\
\cline { 2 - 5 } & 1 & -89.49 & 0.43 & $64.37^{*}$ \\
\hline \multirow{2}{*}{ Specification 9 } & 0 & -96.03 & - & 98.61 \\
\cline { 2 - 5 } & 1 & -69.25 & 0.44 & $69.91^{*}$ \\
\hline
\end{tabular}

(Note) The rank indicates the number of cointegrating equations in a VECM.

* indicates the rank suggested by the test. 